\title{
EXAMINING BUSINESS INNOVATION IN THE SOCIAL RESPONSIBILITY AND ENVIRONMENTAL ACCOUNTABILITY CONTEXTS: EMPIRICAL SYNTHESES FROM GHANA
}

\author{
Alphonse Kumaza* \\ Huazhong University of Science \& Technology, School of Management, Hongshan District, \\ Wuhan City, Hubei Province, People's Republic of China
}

\begin{abstract}
Corporate innovation and technology application for the purpose of improving business profits are a permanent fixation in management. The study explores corporate innovation and its capability to ensure social accountability and environmental responsibility. Innovation is necessary for growth, the maintenance of the market share and for the continual expansion and exploration of business opportunities, yet difficult to secure sustainable communities. The results of an SPSS statistical analysis show that business innovative technology and new thinking capabilities are not so designed to promote environmental accountability and social welfare, but rather to enhance corporations' growth. The insufficient poor understanding of business management of the enterprise's externality contributes to corporations' poor environmental performance. This contribution, which might be the subject matter of possible future research, exposes corporations' inability to promote sustainable stakeholder communities and environmental responsibility, contrary to the perceptions that business innovation works for environmental sustainability.
\end{abstract}

Keywords: sustainability, corporate responsibility, innovation, corporate governance, pollution, externalities, Ghana

\section{JEL Classification: M14, O31, Q56}

\section{INTRODUCTION}

Innovation and sustainability are the key strategies that define the competitiveness of a modern

* Correspondence to: A. Kumaza, University of Science \& Technology, School of Management, 1037 Luo Yu Road, Hongshan District, Wuhan City, Hubei Province, People's Republic of China; e-mail: getalphonse@gmail.com corporation. It suffices to note that sustainability is core to business innovation, knowledge, ideas for better technology deployment, efficient production methods and products, simultaneously ensuring environmental safety. In this way, corporations benefit from the increased market share, growth and profits (Bessant \& Tidd, 2007) at different stages of development and organization, though it is difficult 
to experience high profits and large market share simultaneously; most often, an increased market share results from the price reduction, an increased research cost plus advertisement.

Over the last decades, the established frameworks have been developed for business and/or multinational enterprises (MNEs) to adopt and ensure sustainable production without compromising profits. These guiding frameworks, among other things, include the Industrial Product and Services Life-Cycle (Graedel, Allenby \& Linhart, 1993), the Ecological Upgrading of the Environmental Reform - by using the market system (Spaargaren \& Mol, 1992) and the Triple Bottom Line Structure of Reporting, influenced by social-economic ramifications (Elkington, 1997).

As business is known not to behave responsibly, these guiding principles that corporations pledge to comply with remain a Trojan horse, a white elephant, window dressing and, at best, a charade. Thus, the social change agenda, the sustainable community, and environmental wellbeing have remained peripheral to business, evidencing the catastrophic devastation and pollution of biological systems (Aid, 2004a; Visser, 2010).

Therefore, within the foregoing conceptualization, the paper is aimed at unearthing whether business innovation facilitates environmental sustainability and social accountability or it is not so. The specific objectives include a pursuit of discussion in order to determine the management's understanding of business externalities, the ramifications of an enterprise's operations for host communities and the environment, plus a proof that the self-regulation of corporate commitments is an inadequate strategy for the implementation of a stakeholder initiative and, therefore, should be formalized.

Meanwhile, skepticism abounds that the deployment of contemporary innovations in business production processes incentivizes unsustainable communities and environmental justice. The implications of entrepreneurial innovations for social responsibility also bring to the fore the dreaded complications of the management's scanty understanding the ramifications of innovative technologies for environmental stability, thus representing a gap in the field researched in this study. Judging from this perspective, whether business innovations can promote and support social accountability and environmental responsibility is highly uncertain.

The uncertainty involving business innovation promoting sustainable environmental practices and the social accountability agenda has provoked the following hypotheses for scrutiny:

H1 The management's insufficient and poor
knowledge of business externalities
and insufficient understanding lead to
environmentally unfriendly production practices.
H2 $\begin{aligned} & \text { Inadequate commitments to corporate } \\ & \text { responsibility increase environmental } \\ & \text { degradation and pollution. }\end{aligned}$

The paper argues that entrepreneurial innovation for corporate expansion and growth should take into account environmental accountability and the improvement of livelihoods. Thus, excessive corporate profiting and rent-seeking alone cannot influence a stakeholder support, nor are host communities ready to provide valuable social assets.

The paper uses interviews in order to collate the primary information, while the global online information system provides the secondary data source. An SPSS statistical package via the regression technique is used to analyze the data. In the main, the paper is divided into several sections. The first section is the Introduction, in which the overview, the reasons, the objectives, the gap, and the assumptions are subjected to discussion. The second section deals with the Theoretical Framework including social responsibility institutional theory, multi-national enterprises, the social responsibility construct, and sustainability. In the third section, the Method is elaborated, whereas the fourth, the fifth and the sixth sections are an explanation of the Empirical Results, Discussion and Conclusion, respectively.

In this paper, business is used interchangeably with MNEs and denotes the mother companies whose productive activities transcend national borders. Corporate responsibility is operationalized as those activities aimed at social accountability and environmental sustainability. Corporate governance 
signifies business governance systems and the board's responsibility of oversight in managing organizational objectives, plus ensuring social and environmental accountability. The study is constrained by the funds, which results in a limited data collation for analyses. Onsite interviews and survey data acquisition are, frankly, financially exhausting.

That innovation, including technology application, increases corporate value, wealth and expansion, but does little for social responsibility and environmental accountability, implies that managers lack understanding for the ramifications of business externalities, underscoring meagre stakeholder commitments. This goes to validate the proposition that corporate responsibility is inadequately compensated for by business disproportionate profits and rent-seeking. It, therefore, invigorates the call for the formalization of the current self-commitment strategy so as to ensure the certainty and security of CSR undertakings.

\section{THEORETICAL FRAMEWORK}

\section{Institutional Theory of Social Responsibility}

From institutional theory perspectives, corporate citizenship is a governance system which acknowledges stakeholder constituencies' vast interests. In this context, A. B. Carroll (1999) references corporate accountability as an obligatory task through legal compliance or a societal expectation; yet some scholarly articles highlight its benevolent character.

D. Vogel (2006) describes the strategies of the organizations which seek a conducive working atmosphere for their workers, advance communities' concerns and benefit business as constituting social responsibility. This view agrees with the agency theory and likens the explanation of business characteristics in management research (Garriga \& Melé, 2004).

Unfortunately, the charity character of corporate responsibility even receives scholarly praiseworthiness in the prominent policy papers of the leading business groups (Kinderman, 2012), including the Employment Green Paper (2001), which defines the construct as the voluntary commitment of an enterprise seeking stakeholder needs. Nonetheless, the theory seeks to place social responsibility clearly within a broader field of the state-influenced regulation which reduces a business-centered approach; the mechanism considered is, however, inconclusive (Orlitzky \& Swanson, 2008).

The theory also frowns on the view that corporations embrace social responsibilities so as to increase their financial performance. This thinking, therefore, blurs the understanding of the construct and undermines the enterprise's motivation for engaging itself in providing social responsibility. Corporate responsibility is an activity which should be upheld to deemphasize the construct's long-standing view as business benevolence, making social undertakings and initiatives mythical for some unheedful corporations.

Furthermore, great differences exist globally amongst regions and countries in understanding the construct and, being mostly Global North countries' concept before spreading wild to Global South economies, corporate responsibility seeks to moderate business value and profit maximization proposition. To employ efficiency and profit maximization logic in explaining corporate entities' engagement in interventions in host communities does not carry weight because the evidence suggests that most Japanese and European enterprises do not embrace the concept; yet, they are successful and break even (Matten \& Moon, 2008).

However, most enterprises rather become apprehensive about social accountabilities (Banerjee, 2000) and encourage unfair environmental practices (Jermier, Forbes, Benn \& Orsato, 2006) due to the absence of a policy on supporting corporate commitments (Crouch, 2004). This development demonstrates the fact that enterprises represent entities important, rather than just self-centered and parochially profit-driven and rent-seeking agents in society. Although complying with social responsibilities promotes business financial performance (i.e. quantifying the social license 
and legitimacy in monetary value), using this as the foundational rationality for understanding the construct is flawed.

The theory also views corporate bodies as a political creation with an initial "limited liability" to operate and pursue stakeholder's goals and values, gradually, however, taking over the economy (Roy, 1999), making corporate authority an issue of employment and social equality (Parkinson, 2003). Thus, corporate entities are seen penetrating cultures, prompting understandings and practices surrounding such enterprises as McDonalds', Starbucks (Ritzer \& Jurgenson, 2010), and Disney in the sphere of consumption (Bryman, 1999) and the immediate gender consideration (Orenstein, 2011).

More so, the theory considers corporate enterprises as having linked political power via informal rules in order to establish legitimacy (North, 1990) while firmly placing social responsibility in the hands of management because it is important to corporations. This, therefore, confirms that the CSR constitutes the key business component for wealth creation, growth and development.

Meanwhile, the so-called capitalism variety dimensions and multi-stakeholder involvement are economic coordination issues, exhibiting themselves in different economic systems and Western and European countries' markets, whereas the institutional distinction is linked to different engagements (Aguilera, Williams, Conley \& Rupp, 2006).

It is, however, surprising that organizational theorists spent a lot of time in theorizing the environmental impact on corporations or organizations, rather than the impact of business on environments. However, now is the right time for organizational theorists to integrate such efforts and energies for the purpose of unearthing how business organizations also alter the natural environment while creating their own environments and other sectors, which receives little attention from corporate entities.

Some authors indicated that research in the management of the global operations of transnational conglomerates had been adaptive (Westney \& Zaheer, 2001; Geppert, Matten \& Walgenbach, 2006). Thus, the interdisciplinary theory that explains business vis-àvis society should be developed through institutional theory in order to have it better understood. Institutional theory, however, attempts to clarify this phenomenon from a two-pronged approach, namely institutional dynamics and institutional diversity.

\section{Multinational Enterprises}

Transnational or MNEs are becoming influential in international manufacturing due to the increased availability of finance movement. International business development and operations have, therefore, altered corporate operating environments by introducing serious ecological ramifications.

Transnational conglomerates are, therefore, firms which manufacture global merchandises, looking for an inexpensive location to increase their profits, and unceasingly revolutionizing through a search for strategic ideas, including technology, product innovation, and novel corporate approaches. Similarly, the ownership, management, the strategy, and the structure are MNEs' key features (Root, 1994) emphasizing the originalities of ownership and transnational enterprises, as in the Unilever and Shell conglomerates owned by the British and the Dutch, respectively. Furthermore, MNEs are to be managed by administrators and CEOs, who are the citizens of the enterprise's country of origin, which is a mandatory requirement.

Typically, the headquarters are staffed with the management who understand the enterprise's country's priorities and the business strategy to be adopted, which includes global profit maximization, plus strategies characteristic of affiliate countries. Most often, promising multinational enterprises utilize a mixed world-oriented strategy which on its part is adaptable to the conditions of the local market.

F. R. Root (1994), therefore, describes an MNE as the mother company of global dimensions, which produces from different countries via its several 
divisions upon direct decisions made by its affiliate firms, implements international business strategies, marketing, provides finance and staffing. Moreover, most multinationals owe few obligations to the countries they are amalgamated with.

\section{Business Innovation}

Innovation is the knowledge of how to create value, involving the development and execution of new ideas so as to produce an entirely sophisticated, novel and improved products, processes and services (Hon, Bloom \& Crant, 2014). Deductively, innovation involves comprehensive and general management programs, including new practices and responsibilities through a revolutionized change of mindsets and values contingent upon necessities for a broad, continuous and systematic transformation.

Developments in technology, coupled with the changing dynamics of know-hows, can springboard innovation and strategic business transformation to the levels that, therefore, might encourage huge profits. However, business willingness to deploy obsolete technologies, which are cheaper and increase profits, although at a huge cost to corporate operating environments and countries, where environmental standards are weak and, most frequently, nonexistent, can increase government surveillance in that transnational conglomerates are forced to declare essential details, including site plans and ramifications for operating environments.

Meanwhile, technology is presumed to transform and facilitate business operations, increase profits and reduce production cost; yet, obsolete technologies are still being deployed in countries. While incessant environmental catastrophes necessitate know-hows for the environmentally sound and friendly methods of production, old technologies continue to be used, partly due to the sheer ignorance of the consequences for the business itself and the very operating environments.

Notwithstanding the foregoing, multinational enterprises are required to be socially acceptable in order for them to undertake legitimate operations and, therefore, they must embrace such practices and methods that encourage an efficient and effective technology use in order to ensure high returns on production factors and maintain the sustainability of their host environments. Thus, the business innovation recognized in technology must ensure a good and sound energy use for the purpose of achieving environmental safety and the sustainability of business operating environments. Typically, measures must include the introduction of the technologies that ensure cleaner and safer energy utilization. Intuitively, the enterprises that use the landmass involving clearing woodlots and forests are to be supportive of regenerative measures and contribute to providing the support initiatives that are environmentally friendly. Moreover, corporate managements are increasingly encouraged to instill environmentally responsible behavior in their workplaces, making the business innovation agenda meaningful to communities since innovation only transcends technology.

Proper environmental disclosures by and a proper reporting system of an MNE must reflect conditions and practices on the ground while exhibiting high value and responsibility obligations. They must also appropriately implement these values through the communication system in order to allow business human capital to be abreast of compliant injunctions. Audit disclosures, be they good or bad, are key to the continuous innovative practices of a business intended to influence the community understanding, acceptance and legitimacy.

Meanwhile, the international guidelines set forth are unheeded to since corporate ethics are nothing but what business perceives as its responsibility and, very often, depend on moral convictions. Perhaps the most tragic environmental disaster was the Union Carbide's accident in India in 1984, which caused more than 2,500 deaths and impairment to people (Zagury, Bernard, Leonard, Cheynier, Feldman, Sarin \& Gallo, 1986). While water pollution occurs primarily due to the discharge of industrial hazardous wastes into local water bodies, thus rendering local rivers unusable, a reduction in the quality of the air due to contamination in industrial centers, which leads to increased respiratory and other diseases. 
The foregoing accounts clearly demonstrate a lack of the management's understanding of business externalities since the deployment of old technologies increases the problems of security, safety, and the quality of life, which in turn negatively affects a business and its operating environments.

\section{Corporate Responsibility Construct}

Corporate citizenship is an evolving concept defying definitional theories. A body of studies indicate many definitions, without those emerging in methodological identification problems. However, Bowen's definition (1953), which emphasizes the effects of corporate operations on society and communities, for which plans should be afoot in order to remedy them, is important. This definition unquestionably provides us with the leads for the current definitions and establishes a harmony between corporate authority and business responsibility.

While conceptualizing that a company is formed just to amass wealth is one reason, and just as deep thinking reveals other obligations that must be fulfilled, communities in which business activities take place should benefit from the wealth created, the social obligations of the business, according to A. B. Carroll (1999), covers the socio-economic, legalethical plus discretionary motivations. Undoubtedly, this definition is widely cited in modern corporate responsibility discussions.

The view that the prosperity of a business hinges high on environmental sustainability is supportive of the argument that a business must embrace the corporate responsibility agenda in order to compensate stakeholder communities. Thus, the social responsibilities agenda recognizes the fact that a business classifies its participants and integrates their values, necessities and ambitions in the policies, strategies and everyday activities of the organization.

To delineate the boundaries of corporate citizenship, A. B. Carroll (1999) establishes a four-pronged CSR principle, which includes economic, legal, ethical and philanthropic obligations. Economic responsibilities relate to the productive capacity of a business with respect to the creation of opportunities and ensuring optimal wages. To achieve these value creation objectives, other resources, including technology, are deployed. As the beneficiary of production proceeds, the business must fulfill its tax obligations for the purpose of developing the infrastructure of the country of its incorporation. Therefore, the economic responsibility of the business relates to delivering products and being profitable. Indeed, seven economic activities are delineated, which include satisfying customers by providing them with real-value commodities; earning profits for investors; creating new wealth; promoting social values (as their wages rise) through new jobs; defeating envy, treating people equitably and improving lives; promoting innovation; and avoiding the exploitation of the poor and underprivileged majority (Novak, 1996).

It is necessary that laws should be passed in order to regulate business behavior because corporations cannot be trusted for acting lawfully; hence the basis for legal responsibility. However, laws have a limited scope and only cover what is known and what is about to happen, since human actions determine the present circumstances of the law, and mere provision of a legal minimum for business conduct (which is reactive, instructing doing things) is inadequate.

Again, ethical responsibilities are people's moral rights exercised (Smith \& Quelch, 1993) and inclusive of social norms, institutions, and decisions, either expected (positive) or prohibited (negative), in society, although not written laws (Carroll \& Shabana, 2010). These injunctions, therefore, constitute business ethical obligations in stakeholder communities. Nowadays, society disregards productivity as moral justification for a business's generation of wealth, but as non-economic effects on society, which includes the employee and customer welfare system, stakeholders and business operating environments.

Discretionary obligations are the voluntary services that compensate people and societies because corporations operate in communities and their activities impact social values. Businesses are considered to be good citizens not by their economic 
performances, but rather by their social contributions that lift the poor from poverty and squalor. The contract of engagement is changing, and a business must serve wide-ranging social needs (Chewning, Eby \& Roels, 1990).

That corporate decision-making negatively affects communities and lives support an implied corporate/ social contract - a position strongly conceived by theorists, which spells out the social expectations of a business and business decision-makers' specific responsibilities (Beuachamp \& Bowie, 1983) because it has links with people's welfare and better living standards.

It further posits that social progress should weigh equal in balance with an enterprise's economic progress, and as social institutions, corporations must join hands and build structures amongst which the family and the educational system to improve living conditions (Chewning et al, 1990) are. The modern corporate world is characterized by professional managers, whose decisions impact communities (Miller, 1993), while exploiting societal resources so as to enrich corporate industrial objectives.

A growing consensus, therefore, suggests that a business must assist in solving corporate externalities since an enterprise's taxes alone are insufficient (Jamal \& Bowie, 1995) to ameliorate appalling environmental pollution. Indeed, a business possesses massive economic resources, including know-how and financial power (Lippke, 1996), to develop host communities if it so wishes.

\section{Sustainability}

Sustainability is variously defined by emphasizing preservation, thus entailing the satisfaction of the present needs of today's generation without compromising those of future generations (Visser, 2007) and long-term operation and envisioning a "more measured view" of resource consumption, simultaneously promoting growth (Hawkins, 2006). This implies a generation's capability to sustain and keep the balance between the present and future needs (Blowfield \& Murray, 2008). Economist Robert
Repetto's "Natural Capitalism" observes that when nation states deplete their mineral wealth, extinct the existing tree population, fishes, and wildlife, and cause the erosion of the soil and pollute springs and wells for mankind's immediate gains, a business should endeavor to adopt the production methods that encourage the stability of its operating environments (Abuyuan, Hawken, Newkirk \& Williams, 1999).

\section{METHODS}

The methodology is so designed to place the study in the scientific supposals and approaches reflecting the imperatives of research traditions. The field information and the secondary data obtained from the global online information system generated the overall dataset for the analysis. Indeed, the established (secondary) data provide the baseline for empirical data gathering, without which, however, empirical data collation is impossible.

Interviews were conducted with the representatives of the four mining transnational conglomerates (namely, Goldfields Ghana, Asanko Gold Ghana, Golden Star Resources, and African Mining Services) selected from the study's population. The interviewees include the corporate heads and their deputies, together with a host of the management officers manning the Security, Environment and Human Resource, and other portfolios. However, the investigation goes an extra mile to gather individual-level data from the community opinion leaders, the representatives of the institutions, as well as the non-governmental actors in mining exploration and development aimed at authenticating and cross-referencing the obtained company-level data.

The focused/semi-structured interview technique is deployed so as to gather field data for a thorough scrutiny, which encourages the investigation of interview details and processes. The onsite interviews also make the investigation investigate the studied objects. Macro-level information is obtained from the 30 management staffers of the mining transnational enterprises. Information on the impacts of mining 
on the communities is vigorously elicited, pursued and recorded. This information aims to discover the enterprises' management's understanding of the prospecting ramifications for social life and the environment, the safeguards and/or strategies adopted to curb these challenges, and how innovative technologies (whether old or new) alter business operating environments and natural ecological biodiversity. Information on the communitysupport and future considerations are also pursued. The investigation used the prepared questions subsequently altered for the purpose of dynamism of and adequate responses by the respondents.

In order to validate and cross-examine the companylevel data, the key fifty (50) participants were interviewed in the investigation. Although the individual-level information is merely aimed at crossreferencing the corporate data, it legitimizes the data collation process and empowers the investigation to identify misleading responses for the reconciliation purpose.

The research employs regression analysis in deriving the predictors and the unknown variables for the predictions of the study. The deployment of this technique, as an SPSS statistical package, stems from its measure for the cause and the effect within and among the variables. Meanwhile, as a statistical prediction tool used for the prediction of variables, given another when those variables are interrelated, it shows the mathematical average measurement of the relationships between the variables, and as such includes the measure which is the unknown variable predicted from the known. It reveals the estimates of the dependent variable from the independent ones, and also indicates the error involved in such approximations.

Moreover, regression identifies the correlation and the actual relationship that enables the estimation of the value which it is valid for. The dependent variable is chosen at random, whereas those fixed are the independent variables. In the regression calculation, one dependent measure is selected, but many independent variables are subjected to consideration. The research study indicates that the regression analysis only provides the confidence levels to the investigation that the predictions are all right and correct, instead of proving the claim.

In the main, the information collected and obtained from the interviews and the survey data are triangulated in the data analysis for obtaining the results. The triangulation methodology is justified and credited for integrating methods (Denzin, 1970; Denzin, 1992). Indeed, this method becomes an excellent starting point for an empirical research study and receives a much authorial acknowledgement (Sayer, 2000; Danermark, Ekström, Jakobsen \& Karlsson, 2002) hence its deployment for this study to incentivize the investigation into wide-ranging techniques and dissimilar phenomena.

\section{EMPIRICAL RESULTS}

The statistical experimental outcomes are intended to highlight the instruments and measures that are necessary for the authentication of the study's overarching of the aims and objectives, together with the assumptions in the other, for the purpose of synergizing the measurement findings. Indeed, the "Model Summary", which shows associations between the predictor and the outcome, indicates statistical significance, whereas the "Analysis of Variance" reports the regression equation and the variable inconsistency demonstrating the significance of the model significance and the predictive capability of the outcome variables. Supporting the aforementioned credibility, the p-values in the regression coefficients are statistically significant and, therefore, strengthen the predictors' predictive ability for unknown outcomes.

The R column (Table 1) represents the variable, where $r=0.977^{\mathrm{a}}$, demonstrating the strong relationships between the variables (the predictor and the outcome). In a similar fashion, the $\mathrm{R}^{2}(0.955)$, which is statistically significant, determines the variance proportion of the outcome. It, therefore, means that the model predictor has the capability of predicting the outcomes. The overall standard error (0.30060) 
shows an insignificant value, and makes the variables closer to the regression limit.

Table 1 Model Summary

\begin{tabular}{c|cccc}
\hline Mode & R & R Square & $\begin{array}{c}\text { Adjusted } \\
\text { R Square }\end{array}$ & $\begin{array}{c}\text { Std. Error of the } \\
\text { Estimate }\end{array}$ \\
\hline 1 & $.977 a$ & .955 & .952 & .30060 \\
\hline
\end{tabular}

Predictors: (Constant), The board's diversity ensures an effective CG for the CSR, Decoupling the CSR from the Corporate Affairs Department attracts a better response from the management, A disregard for the $C G$ rules negatively affects the CSR.

Source: Author

The analysis of variance (Table 2), also called ANOVA, describes the regression equation and the variability (inconsistency). The Source column includes regression, both residual and total, where the corresponding values (69.722 and 3.253) denote the variability of the response variance. Thus, ANOVA determines the model significance and the predictive capability of the outcome variables. The $p<.001$ is statistically significant and, therefore, makes the model outcome predictor a suitable measure, where $\mathrm{F}$ $(3,36)=257.20, \mathrm{p}<.001$.

The $\mathrm{R}$ (Table 4) shows an association between the variables, where $r=0.886^{\mathrm{a}}$, and signifies the predictor, and the reaction variables are comparable. Additionally, $\mathrm{R}^{2}(0.785)$ is the determinant of the variability of the variance, which is also statistically significant, meaning that the model can predict the research outcomes. Likewise, the entire standard error (0.21822) shows an insignificant value, which means the measures are nearer the regression domain.

Table 5 describes the computed equation and the variable inconsistency. The matrix consists of the Regression, Residual and Total, where the corresponding values (6.261 and 1.714) denote the unevenness of the response measure. Thus, ANOVA determines the model significance and the predictive capability of the outcome variables. The $p<.001$ indicates statistical significance and, therefore, makes the regression model a valid predictor of the outcome, where $\mathrm{F}(3,36)=43.83, \mathrm{p}<.001$.

\section{DISCUSSION}

This study examines the innovation of a business and its ramification with respect to its social accountability and environmental responsibility. It further discusses whether the innovation in and technological improvements of a business in the domain of the production practices and other management procedures lead to natural environment sustainability and stakeholder constituents. Evidence shows that corporate innovation is internalized for

Table 2 ANOVA ${ }^{a}$ (Analysis of Variance)

\begin{tabular}{cl|ccccc}
\hline \multicolumn{1}{c|}{ Model } & Sum of Squares & df & Mean Square & F & Sig. \\
\hline \multirow{3}{*}{1} & Regression & 69.722 & 3 & 23.241 & 257.203 & $.000^{\text {b }}$ \\
& Residual & 3.253 & 36 & .090 & & \\
& Total & 72.975 & 39 & & & \\
\hline
\end{tabular}

a. Dependent Variable: The management have the insufficient knowledge of the business externalities and the impacts on the communities.

b. Predictors: (Constant), The board's diversity ensures an effective CG for the CSR, Decoupling the CSR from the Corporate Affairs Department attracts a better response from the management, A disregard for the CG rules negatively affects the CSR. 
the benefits of a business, not the external stakeholder constituencies, deflating and negating the paper's overarching objective that business innovation facilitates environmental sustainability and/or responsibility, and social accountability.

Contrary to the general perception that, through research and development (R\&D), the know-how and innovation of a business advances the host communities' interest in involving itself in ecologically sound practices, an enterprise's innovation, alas, is found to be purposefully designed to seek the expansion, growth, and capital accumulation of such a business. The ensuing deliberations validate the suppositions alleged in the study.

Table 3 contains the p-value of each term and the statistical tests for the constructs and the coefficients. The p-value (.001, .001 and .002) of each term is statistically significant, showing the predictor is prominent to be interpreted because the variations in the predictor are related to the changes in the response variables. That the selected variables are statistically significant, whereas the abundant evidence that the constructs are monotonically correlated and, therefore, validate the extrapolations of the research means that the results are assumptions-supportive. Additionally, the t-values (-22.756, 24.515, -3.368) indicate the variations of little significance relative to the constructs and are comparable and suitable for making predictions. Likewise, the standard errors (.135, .107 and .098) show the insignificant values that are indicative of the fact that the measures are closer to the regression limit, thereby supporting the research expectations.

Meanwhile, the constant of the unit change of the model (9.924) results in this measure (-3.082) of change

Table 3 Regression Coefficients ${ }^{\mathrm{a}}$

\begin{tabular}{|c|c|c|c|c|c|c|}
\hline & \multirow[t]{2}{*}{ Model } & \multicolumn{2}{|c|}{ Unstandardized Coefficients } & \multirow{2}{*}{$\begin{array}{l}\text { Standardized } \\
\text { Coefficients } \\
\text { Beta }\end{array}$} & \multirow[t]{2}{*}{$t$} & \multirow[t]{2}{*}{ Sig. } \\
\hline & & B & Std. Error & & & \\
\hline \multirow{4}{*}{1} & (Constant) & 9.924 & .724 & & 13.711 & .000 \\
\hline & $\begin{array}{l}\text { A disregard for the } \mathrm{CG} \text { rules } \\
\text { negatively affects the CSR }\end{array}$ & -3.082 & .135 & -.913 & -22.756 & .000 \\
\hline & $\begin{array}{l}\text { Decoupling CSR from Corporate } \\
\text { Affairs Department attracts better } \\
\text { management }\end{array}$ & 2.629 & .107 & .968 & 24.515 & .000 \\
\hline & $\begin{array}{l}\text { The board's diversity ensures an } \\
\text { effective CG for the CSR }\end{array}$ & -.329 & .098 & -.121 & -3.368 & .002 \\
\hline
\end{tabular}

Dependent Variable: The management have the insufficient knowledge of the business externalities and the impacts on the communities.

Source: Author

Table 4 Model Summary

\begin{tabular}{c|cccc}
\hline Model & R & R Square & Adjusted R Square & Std. Error of the Estimate \\
\hline 1 & $.886 a$ & .785 & .767 & .21822 \\
\hline
\end{tabular}

Predictors: (Constant), A disregard for the CG rules negatively affects the CSR, A weak corporate board disincentivizes the CSR, Decoupling CSR from the Corporate Affairs Department attracts better management. 
Table 5 ANOVA $^{a}$ (Analysis of Variance)

\begin{tabular}{|c|c|c|c|c|c|c|}
\hline & Model & Sum of Squares & df & Mean Square & $\mathrm{F}$ & Sig. \\
\hline \multirow{3}{*}{1} & Regression & 6.261 & 3 & 2.087 & 43.825 & $.000^{\mathrm{b}}$ \\
\hline & Residual & 1.714 & 36 & .048 & & \\
\hline & Total & 7.975 & 39 & & & \\
\hline
\end{tabular}

Dependent Variable: The CSR is an inadequate compensation for corporate profiting and rent-seeking.

Predictors: (Constant), A disregard for the CG rules negatively affects the CSR, A weak corporate board disincentivizes the CSR, Decoupling the CSR from the Corporate Affairs Department attracts better management.

Source: Author

in "A disregard for the CG rules negatively affects the CSR". Likewise, the constant of a single-unit change of the model (9.924) leads to a change in the measures (2.629 and -.329) and confirms the "Decoupling the CSR from the Corporate Affairs Department attracts better management" and "The board's diversity ensures an effective CG for the CSR", respectively.

The ordinary interpretation of the statistical results shows that little is done about the externalities of the business and their ramifications for the stakeholder communities and the environment because the management possess the knowledge and understanding that are scanty, which corroborates the proof that the self-regulation of corporate commitments is an inadequate strategy for the implementation of the stakeholder initiative and, therefore, should be formalized.

A conclusion is, therefore, drawn that the leadership of the management of a business, including transnational ones, hardly understand the practical implications of corporate activities for sustainability. Intuitively, pollution is an after-effect observable in the illness of humans, a loss of the fauna and flora, and a reduction in the quality of the aquatic resource, which regrettably are noticeable only to the human eye. Thus, with an adequate knowledge and understanding, concrete steps will be taken in order to reduce the causative factors and also lessen the impacts. No doubt, transnational enterprises externalize the production cost, resulting in horrific and catastrophic environmental ramifications, poverty, and health problems (Aid, 2004b; Armstrong, 2005; Visser, 2010).
Again, the result also demonstrates a huge piece of evidence showing that the current self-regulation of corporate commitments and undertakings is informal, ad hoc, and unsystematic, and that it delivers scanty outcomes, validating the proposition for formalizing the strategy to incentivize appropriate and compensatory outcomes.

In a nutshell, the paper demonstrates that the corporate management has the insufficient knowledge of the deleterious activities of the business and their impacts on the sustainability of the communities, as a disservice to corporations, themselves, and the stakeholder communities, since the cost of externalities affects both the business and its operating environments alike.

Similarly to Table 5, Table 6 shows the regression results including the p-values and the coefficients. The statistically significant $p$-value $(<0.05)$ demonstrates that the predictor has to be taken into consideration and reported since changes in the predictors' variables affect the response variables.

Therefore, the three coefficients $(.429, .429$ and .571$)$ indicate statistical significance $(.001 \times 3)$, meaning the constructs are monotonically related. Moreover, the t-values $(3.674,4.409,5.060)$ indicate the difference of small significance in the variables of the model, suggesting that the constructs share a high degree of association. Furthermore, the standard errors (.117, .097 and .113), which are the average distance from the regression line, show insignificant measures, indicating the measures are closely related. 
Table 6 Regression Coefficients ${ }^{\mathrm{a}}$

\begin{tabular}{|c|c|c|c|c|c|c|}
\hline & Model & Unstandar & Coefficients & $\begin{array}{l}\text { Standardized } \\
\text { Coefficients }\end{array}$ & $t$ & Sig. \\
\hline & & B & Std. Error & Beta & & \\
\hline & (Constant) & -.857 & .505 & & -1.697 & .098 \\
\hline & $\begin{array}{l}\text { A weak corporate board } \\
\text { disincentivizes the CSR }\end{array}$ & .429 & .117 & .365 & 3.674 & .001 \\
\hline 1 & $\begin{array}{l}\text { Decoupling the CSR from the } \\
\text { Corporate Affairs Department } \\
\text { attracts better management }\end{array}$ & .429 & .097 & .478 & 4.409 & .000 \\
\hline & $\begin{array}{l}\text { Disregard for CG rules negatively } \\
\text { affects CSR }\end{array}$ & .571 & .113 & .512 & 5.060 & .000 \\
\hline
\end{tabular}

Dependent Variable: The CSR is an inadequate compensation for corporate profiting and rent-seeking.

Source: Author

More importantly, the value of the constant (-.857) implies that the model takes the mathematical value of -0.857 given to the independent predators. Therefore, the unit change in the constant (-.857) results in this measure (.429) of change in "A weak corporate board disincentivizes the CSR". Furthermore, the variation of the model's constant unit (-.857) changes the measures (.429 and .571) and confirms the validity of the "Decoupling the CSR from the Corporate Affairs Department attracts better management" and "The board's diversity ensures an effective CG for the CSR", respectively.

The foregoing means that, on the pretext of corporate commitments, which are woefully scanty (Frynas, 2005) owing to the absence of the policy on the regulation and implementation of initiatives, corporate taxes and royalties are insignificantly negligible for any development of the infrastructure that make the communities in which a business operates worse off. Additionally, certain transnational conglomerates do not even pay taxes at all (Akabzaa, 2009), either due to weak or due to non-existent policies and regulations (Auty, 1998). This, therefore, supports the consensus that the discussion on the management of the resource wealth has shifted from te needed, careful and measured industrial policy to the propositions for independent institutions and investment funds (Harberger, 1994; McMahon, 1997;
Auty \& Gelb, 2001; Frezzolini, Teofoli, Cianchini, Barduagni, Ruffelli, Ferranti, Puddu \& De Pita, 2002).

The above confirms the fact that the business does little to ensure its social accountability and environmental responsibility, though corporate profits continue to grow. The exploitation of the stakeholder resources for the purpose of making profits hardly serves the interest of the business since the increased financial performance might be perceived as less socially good, resulting in rising income in favor of the investor and the upper management (Barnett, 2007), and may motivate cynicism and violence from the local population.

The call for the formalization of self-regulation is for the purpose of ensuring the sincerity of the business, which otherwise will sanction the stereotypes for increased profits and business externalities. No wonder T. M. Devinney (2009) argues that environmental sustainability and corporate accountability to its stakeholder constituencies have been carelessly managed.

\section{CONCLUSION}

Business innovation and its effects on environmental sustainability and social accountability were 
examined. We were determined to discover whether managers understand business negative implications for stakeholder communities and the environment or not, and whether the self-regulation of corporate commitments is a poor strategy for the execution of the stakeholder's initiative. Statistical evidence proves that, contrary to the generally held opinion, corporate innovation seeks to benefit the environments in which a business operates and support environmental accountability, and the gains are rather internalized so as to promote the expansion, growth, and profitability of an enterprise.

Since innovation, which provides new knowledge and thinking, is skewed towards the success of a business, there is little room for managers to be motivated for pursuing environmental sustainability and social accountability concerns because corporate learning is becoming innovation for the success of a business. In this view, the assumption that "The management's insufficient and poor knowledge of business externalities and insufficient understanding lead to environmentally unfriendly production practices" is validated, and the reason why social development, sustainability, and business ethics have remained peripheral, and why the standards having been adopted by the majority of companies, including the internationally recommended regimes and sets of initiatives and guidelines, have all failed to halt the destruction of the natural environment and host communities (Visser, 2010).

In another development, the unification of social responsibility and environmental accountability has received some modest treatment in the literature with a rather casual alignment. This is for the reason of the fact that corporations desire to adopt guidelines, ethics and standards, and also adhere to the aspirations of external stakeholder constituencies while transiting to the existing economic and political scene and practically accommodating and internalizing environmental externalities (Hertel, 2009) so as to increase the commitments of a business towards a conducive working atmosphere and the preservation of ecology via the acquisition of wealth (Mandelbaum, 2007), thereby rendering the considerations of social and environmental sustainability mutually exclusive.
The result establishes the fact that CSR initiatives have been scanty and disproportionately minor in comparison with corporate profits, thus confirming the assumptions.

The continuous viability of a business, including multinational enterprises on the global market, is reliant on innovation for the development of processes and methods, and the reformulation of the development of the product. Given that a business always does the right thing, the growing voice to maintain its operating communities and be environmentally accountable is needless and timewasting. For instance, environmental degradation and/or the complicated market-inadequate measurements for corporate externalities continue to diminish social-ecological resources. However, the analysis reveals that business managers hardly understand corporate externalities and, therefore, do not plan their reduction. This means that business innovation in production processes, methods, and research and development is, at best, internalized for increased profits against environmental sustainability. Astonishingly, corporate innovation correlates with the social accountability and environmental sustainability agenda; yet, managers have an insufficient knowledge of and understanding for business externalities, for which reason the prospects of innovation have no relevance for host communities and the environment.

Indeed, deploying knowledge for the purpose of creating value for entirely sophisticated novel and improved products, processes and services also means that such undertakings should be socially and environmentally sustainable. The paper, unfortunately, wonders whether business innovation is an inversion of environmental pollution and degradation.

Again, the results encapsulating corporate responsibility cannot compensate for the wealth generated from stakeholder communities because social responsibility initiatives are poorly funded and implemented. In this regard, environmental responsibility suffers as commitments are scanty and underfunded, affecting environmental initiatives 
and CSR interventions. In order to make the CSR compensate for business profits and rent-seeking, the ineffectual self-regulation strategy for social accountability and environmental responsibility should be supported through the stakeholder governance model for results.

Empirical data collation is expensive, especially when involving onsite interviews that require inexhaustible funds to conduct. Thus, the funds inadequacy together with human capital restricts and constrains large data for analysis. Managers' insufficient knowledge of and understanding for externalities leads to poor corporate commitments and poor environmental accountability and/or sustainability, which is novel in contemporary research and we hope it will be the focus of further academic scrutiny.

To conclude, we regret the comment made by a powerful individual on Earth that "environmental pollution and degradation are a hoax", which reflects a bigger picture of ignorance amongst the majority of the world's nearly 7 billion population; that is a reason why it is increasingly difficult to cure environmental malice and ensure the stability and ecological sustainability of stakeholder communities.

\section{REFERENCES}

Abuyuan, A., Hawken, I., Newkirk, M., \& Williams, R. (1999). Waste Equals Food: Developing a Sustainable Agriculture Support Cluster for a Proposed Resource Recovery Park in Puerto Rico 1999. CiteSeer ${ }^{x}$.

Aguilera, R. V., Williams, C. A., Conley, J. M., \& Rupp, D. E. (2006). Corporate governance and social responsibility: A comparative analysis of the UK and the US. Corporate Governance: An International Review, 14(3), 147-158. doi. org/10.1111/j.1467-8683.2006.00495.x

Aid, C. (2004a). Behind the mask: The real face of corporate social responsibility. London, UK: Christian Aid

Aid, C. (2004b). Behind the mask: The real face of CSR. London, UK: Christian Aid.
Akabzaa, T. (2009). Mining in Ghana: Implications for national economic development and poverty reduction. In B. Campbell (Ed.). Mining in Africa: Regulation and development (pp. 25-65). Pluto Press, IDRC.

Armstrong, E. (2005). Integrity, transparency, and accountability in public administration: Recent trends, regional and international developments, and emerging issues. United Nations, Department of Economic and Social Affairs, 1-10.

Auty, R. M. (1998). Social sustainability in mineral-driven development. Journal of International Development, 10(4), 487500 .

Auty, R. M., \& Gelb, A. H. (2001). The political economy of resource abundant states. Resource abundance and economic development, 126-144, Working Paper, Washington, DC: World Bank.

Banerjee, S. B. (2000). Whose land is it anyway? National interest, indigenous stakeholders, and colonial discourses: The case of the Jabiluka uranium mine. Organization $\mathcal{E}$ Environment, 13(1), 3-38. doi.org/10.1177/1086026600131001

Barnett, M. L. (2007). Stakeholder influence capacity and the variability of financial returns to corporate social responsibility. Academy of management review, 32(3), 794-816. doi.org/10.5465/amr.2007.25275520

Bessant, J., \& Tidd, J. (2007). Innovation and entrepreneurship. Leicester, UK: Wiley, John \& Sons.

Beuachamp, T., \& Bowie, N. E. (1983). Ethical theory and business. Englewood Cliffs: NJ: Prentice-Hall.

Blowfield, M., \& Murray, A. (2008). Corporate responsibility: A critical overview. Oxford, Oxford University Press.

Bowen, H. R. (1953). Social Responsibilities of the Businessman. NewYork, NY: Harper\&Row.

Bryman, A. (1999). The Disneyization of society. The Sociological Review, 47(1), 25-47. doi.org/10.1111/1467-954X.00161

Carroll, A. B. (1999). Corporate social responsibility: Evolution of a definitional construct. Business \& society, 38(3), 268-295. doi.org/10.1177/000765039903800303

Carroll, A. B., \& Shabana, K. M. (2010). The business case for corporate social responsibility: A review of concepts, research, and practice. International journal of management reviews, 12(1), 85-105. doi.org/10.1111/j.1468-2370.2009.00275.x 
Chewning, R. C., Eby, J. W., \& Roels, S. J. (1990). Business through the eyes of faith. HarperOne.

Crouch, C. (2004). Post-democracy. Polity Cambridge.

Danermark, B., Ekström, M., Jakobsen, L., \& Karlsson, J. C. (2002). Explaining society. Critical realism in the social sciences. London, UK: Routledge, Taylor \& Francis Group.

Denzin, N. (1970). Strategies of multiple triangulation. In N. Denzin (Ed.). The research act in sociology: A theoretical introduction to the sociological method, (pp. 297-313). New York, NY: McGraw-Hill

Denzin, N. (1992). The many faces of emotionality: Reading persona. Investigating subjectivity: Research on lived experience, $17-30$.

Devinney, T. M. (2009). Is the socially responsible corporation a myth? The good, the bad, and the ugly of corporate social responsibility. The Academy of Management Perspectives, 23(2), 44-56. doi.org/10.5465/amp.2009.39985540

Elkington, J. (1997). Cannibals with forks: The triple bottom line of twentieth-century business. Oxford, US: John Wiley \& Son Ltd

Employment Green Paper. (2001). Promoting a European Framework for Corporate Social Responsibility: Green Paper. Office for Official Publications of the European Commission.

Frezzolini, A., Teofoli, P., Cianchini, G., Barduagni, S., Ruffelli, M., Ferranti, G., Puddu, P., \& De Pita, O. (2002). Increased expression of eotaxin and its specific receptor CCR3 in bullous pemphigoid. European journal of dermatology: EJD, 12(1), 27-31.

Frynas, J. G. (2005). The false developmental promise of corporate social responsibility: Evidence from multinational oil companies. International affairs, 81(3), 581-598.

Garriga, E., \& Melé, D. (2004). Corporate social responsibility theories: Mapping the territory. Journal of Business Ethics, 53(1-2), 51-71. doi:10.1023/B:BUSI.0000039399.90587.34

Geppert, M., Matten, D., \& Walgenbach, P. (2006). Transnational institution building and the multinational corporation: An emerging field of research. Human Relations, 59(11), 14511465. doi.org/10.1177/0018726706072888

Graedel, T., Allenby, B., \& Linhart, P. (1993). Implementing industrial ecology. IEEE Technology and Society Magazine, 12(1), 18-26. doi:10.1109/44.192717
Harberger, A. C. (1994). New insights into the growth process: Indian Council for Research on International Economic Relations.

Hawkins, D. (2006). Corporate social responsibility: Balancing tomorrow's sustainability and today's profitability. London, UK: Palgrave Macmillan

Hertel, S. (2009). Human rights and the global economy: Bringing labor rights back in. Md. J. Int'l L. 24(1), 257-269.

Hon, A. H., Bloom, M., \& Crant, J. M. (2014). Overcoming resistance to change and enhancing creative performance. Journal of management, 40(3), 919-941. doi. org/10.1177/0149206311415418

Jamal, K., \& Bowie, N. E. (1995). Theoretical considerations for a meaningful code of professional ethics. Journal of Business Ethics, 14(9), 703-714.

Jermier, J., Forbes, L., Benn, S., \& Orsato, R. J. (2006). The new corporate environmentalism \& green politics. In S. R. Clegg, C. Hardy, T. B. Lawrence, \& W. R. Nord (Eds). The Sage handbook of organization studies. doi:10.4135/9781848608030. n22

Kinderman, D. (2012). 'Free us up so we can be responsible!'The co-evolution of corporate social responsibility and neoliberalism in the UK, 1977-2010. Socio-Economic Review, 10(1), 29-57. doi:10.1093/ser/mwr028

Lippke, R. (1996). Setting the terms of the business responsibility debate," in Ethics in the Workplace: Selected Readings in Business Ethics. Larmer, RA (Ed), West Publishing Company, Minneapolis/St. Paul, MN. St. Paul, MN.

Mandelbaum, D. G. (2007). Corporate sustainability strategies. Temple Journal of Science Technology \& Environmetal Law, 26, $27-42$.

Matten, D., \& Moon, J. (2008). "Implicit" and "explicit" CSR: A conceptual framework for a comparative understanding of corporate social responsibility. Academy of management review, 33(2), 404-424. doi.org/10.5465/amr.2008.31193458

McMahon, G. (1997). The natural resource curse: Myth or reality? Economic Development Institute, Washington, DC: World Bank.

Miller, T. (1993). The well-tempered self Citizenship, culture, and the postmodern subject. The Johns Hopkins University Press. 
North, D. C. (1990). Institutions, Institutional Change and Economic Performance. Cambridge, US: Cambridge university press.

Novak, W. J. (1996). The People's Welfare: Law and Regulation in Nineteenth-century America. North Carolina, US: Univrsity of North Carolina Press.

Orenstein, P. (2011). Cinderella Ate my Daughter: New York, NY: HarperCollins.

Orlitzky, M., \& Swanson, D. (2008). Toward Integrative Corporate Citizenship: Research Advances in Corporate Social Performance. London, UK: Palgrave Macmillan UK.

Parkinson, J. (2003). Disclosure and corporate social and environmental performance: Sompetitiveness and enterprise in a broader social frame. Journal of Corporate Law Studies, 3(1), 3-39. doi.org/10.1080/14735970.2003.11419892

Ritzer, G., \& Jurgenson, N. (2010). Production, consumption, prosumption the nature of capitalism in the age of the digital 'prosumer'. Journal of consumer culture, 10(1), 13-36. doi.org/10.1177/1469540509354673

Root, F. R. (1994). Entry Strategy for International Markets. New York, NY: Lexington Books.

Roy, W. G. (1999). Socializing capital: The rise of the large industrial corporation in America. Princeton, US: Princeton University Press.
Sayer, A. (2000). Realism and Social Science. London, UK: SAGE Publications.

Smith, N. C., \& Quelch, J. A. (1993). Ethics in Marketing. JSTOR.

Spaargaren, G., \& Mol, A. P. (1992). Sociology, environment, and modernity: Ecological modernization as a theory of social change. Society \& natural resources, 5(4), 323-344. doi. org/10.1080/08941929209380797

Visser, W. (2007). Corporate sustainability and the individual. Cambridge Programme for Sustainability Leadership, Paper Series No 1.

Visser, W. (2010). The age of responsibility: CSR 2.0 and the new DNA of business. Journal of Business Systems, Governance and Ethics, 5(3), 7-22. doi:10.15209/jbsge.v5i3.185

Vogel, D. (2006). The Market for Virtue. Washington, US: Brookings Institute press.

Westney, D. E., \& Zaheer, S. (2001). The multinational enterprise as an organization. The Oxford handbook of international business, 1, 101-124. doi:10.1093/ oxfordhb/9780199234257.003.0013

Zagury, D., Bernard, J., Leonard, R., Cheynier, R., Feldman, M., Sarin, P., \& Gallo, R. C. (1986). Long-term cultures of HTLV-III-infected T cells: A model of cytopathology of T-cell depletion in AIDS. Science, 231, 850-854.

Received on $3^{\text {rd }}$ November 2018, after revision, accepted for publication on $12^{\text {th }}$ December 2018

Published online on $28^{\text {th }}$ December 2018

Alphonse Kumaza is a senior tourism officer at the Ministry of Tourism, Arts and Culture, Ghana, and works at the Research and Statistics Department. Since 2015, he has been awarded a scholarship for a Ph.D. degree in Business Administration, majoring in Enterprise Strategic Management and Managerial Economics at the School of Management, Huazhong University of Science \& Technology (HUST), Wuhan, China. His research interests are in Corporate Responsibility, Corporate Governance, and Policy. 


\title{
EXAMINING BUSINESS INNOVATION IN THE SOCIAL RESPONSIBILITY AND ENVIRONMENTAL ACCOUNTABILITY CONTEXTS: EMPIRICAL SYNTHESES FROM GHANA
}

\author{
Alphonse Kumaza* \\ Huazhong University of Science \& Technology, School of Management, Hongshan District, \\ Wuhan City, Hubei Province, People's Republic of China
}

Corporate innovation and technology application for the purpose of improving business profits are a permanent fixation in management. The study explores corporate innovation and its capability to ensure social accountability and environmental responsibility. Innovation is necessary for growth, the maintenance of the market share and for the continual expansion and exploration of business opportunities, yet difficult to secure sustainable communities. The results of an SPSS statistical analysis show that business innovative technology and new thinking capabilities are not so designed to promote environmental accountability and social welfare, but rather to enhance corporations' growth. The insufficient poor understanding of business management of the enterprise's externality contributes to corporations' poor environmental performance. This contribution, which might be the subject matter of possible future research, exposes corporations' inability to promote sustainable stakeholder communities and environmental responsibility, contrary to the perceptions that business innovation works for environmental sustainability.

Keywords: sustainability, corporate responsibility, innovation, corporate governance, pollution, externalities, Ghana

JEL Classification: M14, 031, Q56

\section{INTRODUCTION}

Innovation and sustainability are the key strategies that define the competitiveness of a modern

* Correspondence to: A. Kumaza, University of Science \& Technology, School of Management, 1037 Luo Yu Road, Hongshan District, Wuhan City, Hubei Province, People's Republic of China; e-mail: getalphonse@gmail.com corporation. It suffices to note that sustainability is core to business innovation, knowledge, ideas for better technology deployment, efficient production methods and products, simultaneously ensuring environmental safety. In this way, corporations benefit from the increased market share, growth and profits (Bessant \& Tidd, 2007) at different stages of 
development and organization, though it is difficult to experience high profits and large market share simultaneously; most often, an increased market share results from the price reduction, an increased research cost plus advertisement.

Over the last decades, the established frameworks have been developed for business and/or multinational enterprises (MNEs) to adopt and ensure sustainable production without compromising profits. These guiding frameworks, among other things, include the Industrial Product and Services Life-Cycle (Graedel, Allenby \& Linhart, 1993), the Ecological Upgrading of the Environmental Reform - by using the market system (Spaargaren \& Mol, 1992) and the Triple Bottom Line Structure of Reporting, influenced by social-economic ramifications (Elkington, 1997).

As business is known not to behave responsibly, these guiding principles that corporations pledge to comply with remain a Trojan horse, a white elephant, window dressing and, at best, a charade. Thus, the social change agenda, the sustainable community, and environmental wellbeing have remained peripheral to business, evidencing the catastrophic devastation and pollution of biological systems (Aid, 2004a; Visser, 2010).

Therefore, within the foregoing conceptualization, the paper is aimed at unearthing whether business innovation facilitates environmental sustainability and social accountability or it is not so. The specific objectives include a pursuit of discussion in order to determine the management's understanding of business externalities, the ramifications of an enterprise's operations for host communities and the environment, plus a proof that the self-regulation of corporate commitments is an inadequate strategy for the implementation of a stakeholder initiative and, therefore, should be formalized.

Meanwhile, skepticism abounds that the deployment of contemporary innovations in business production processes incentivizes unsustainable communities and environmental justice. The implications of entrepreneurial innovations for social responsibility also bring to the fore the dreaded complications of the management's scanty understanding the ramifications of innovative technologies for environmental stability, thus representing a gap in the field researched in this study. Judging from this perspective, whether business innovations can promote and support social accountability and environmental responsibility is highly uncertain.

The uncertainty involving business innovation promoting sustainable environmental practices and the social accountability agenda has provoked the following hypotheses for scrutiny:

H1 The management's insufficient and poor knowledge of business externalities and insufficient understanding lead to environmentally unfriendly production practices.

H2 Inadequate commitments to corporate responsibility increase environmental degradation and pollution.

The paper argues that entrepreneurial innovation for corporate expansion and growth should take into account environmental accountability and the improvement of livelihoods. Thus, excessive corporate profiting and rent-seeking alone cannot influence a stakeholder support, nor are host communities ready to provide valuable social assets.

The paper uses interviews in order to collate the primary information, while the global online information system provides the secondary data source. An SPSS statistical package via the regression technique is used to analyze the data. In the main, the paper is divided into several sections. The first section is the Introduction, in which the overview, the reasons, the objectives, the gap, and the assumptions are subjected to discussion. The second section deals with the Theoretical Framework including social responsibility institutional theory, multi-national enterprises, the social responsibility construct, and sustainability. In the third section, the Method is elaborated, whereas the fourth, the fifth and the sixth sections are an explanation of the Empirical Results, Discussion and Conclusion, respectively.

In this paper, business is used interchangeably with MNEs and denotes the mother companies whose productive activities transcend national borders. Corporate responsibility is operationalized as 
those activities aimed at social accountability and environmental sustainability. Corporate governance signifies business governance systems and the board's responsibility of oversight in managing organizational objectives, plus ensuring social and environmental accountability. The study is constrained by the funds, which results in a limited data collation for analyses. Onsite interviews and survey data acquisition are, frankly, financially exhausting.

That innovation, including technology application, increases corporate value, wealth and expansion, but does little for social responsibility and environmental accountability, implies that managers lack understanding for the ramifications of business externalities, underscoring meagre stakeholder commitments. This goes to validate the proposition that corporate responsibility is inadequately compensated for by business disproportionate profits and rent-seeking. It, therefore, invigorates the call for the formalization of the current self-commitment strategy so as to ensure the certainty and security of CSR undertakings.

\section{THEORETICAL FRAMEWORK}

\section{Institutional Theory of Social Responsibility}

From institutional theory perspectives, corporate citizenship is a governance system which acknowledges stakeholder constituencies' vast interests. In this context, A. B. Carroll (1999) references corporate accountability as an obligatory task through legal compliance or a societal expectation; yet some scholarly articles highlight its benevolent character.

D. Vogel (2006) describes the strategies of the organizations which seek a conducive working atmosphere for their workers, advance communities' concerns and benefit business as constituting social responsibility. This view agrees with the agency theory and likens the explanation of business characteristics in management research (Garriga \& Melé, 2004).
Unfortunately, the charity character of corporate responsibility even receives scholarly praiseworthiness in the prominent policy papers of the leading business groups (Kinderman, 2012), including the Employment Green Paper (2001), which defines the construct as the voluntary commitment of an enterprise seeking stakeholder needs. Nonetheless, the theory seeks to place social responsibility clearly within a broader field of the state-influenced regulation which reduces a business-centered approach; the mechanism considered is, however, inconclusive (Orlitzky \& Swanson, 2008).

The theory also frowns on the view that corporations embrace social responsibilities so as to increase their financial performance. This thinking, therefore, blurs the understanding of the construct and undermines the enterprise's motivation for engaging itself in providing social responsibility. Corporate responsibility is an activity which should be upheld to deemphasize the construct's long-standing view as business benevolence, making social undertakings and initiatives mythical for some unheedful corporations.

Furthermore, great differences exist globally amongst regions and countries in understanding the construct and, being mostly Global North countries' concept before spreading wild to Global South economies, corporate responsibility seeks to moderate business value and profit maximization proposition. To employ efficiency and profit maximization logic in explaining corporate entities' engagement in interventions in host communities does not carry weight because the evidence suggests that most Japanese and European enterprises do not embrace the concept; yet, they are successful and break even (Matten \& Moon, 2008).

However, most enterprises rather become apprehensive about social accountabilities (Banerjee, 2000) and encourage unfair environmental practices (Jermier, Forbes, Benn \& Orsato, 2006) due to the absence of a policy on supporting corporate commitments (Crouch, 2004). This development demonstrates the fact that enterprises represent entities important, rather than just self-centered and parochially profit-driven and rent-seeking 
agents in society. Although complying with social responsibilities promotes business financial performance (i.e. quantifying the social license and legitimacy in monetary value), using this as the foundational rationality for understanding the construct is flawed.

The theory also views corporate bodies as a political creation with an initial "limited liability" to operate and pursue stakeholder's goals and values, gradually, however, taking over the economy (Roy, 1999), making corporate authority an issue of employment and social equality (Parkinson, 2003). Thus, corporate entities are seen penetrating cultures, prompting understandings and practices surrounding such enterprises as McDonalds', Starbucks (Ritzer \& Jurgenson, 2010), and Disney in the sphere of consumption (Bryman, 1999) and the immediate gender consideration (Orenstein, 2011).

More so, the theory considers corporate enterprises as having linked political power via informal rules in order to establish legitimacy (North, 1990) while firmly placing social responsibility in the hands of management because it is important to corporations. This, therefore, confirms that the CSR constitutes the key business component for wealth creation, growth and development.

Meanwhile, the so-called capitalism variety dimensions and multi-stakeholder involvement are economic coordination issues, exhibiting themselves in different economic systems and Western and European countries' markets, whereas the institutional distinction is linked to different engagements (Aguilera, Williams, Conley \& Rupp, 2006).

It is, however, surprising that organizational theorists spent a lot of time in theorizing the environmental impact on corporations or organizations, rather than the impact of business on environments. However, now is the right time for organizational theorists to integrate such efforts and energies for the purpose of unearthing how business organizations also alter the natural environment while creating their own environments and other sectors, which receives little attention from corporate entities.
Some authors indicated that research in the management of the global operations of transnational conglomerates had been adaptive (Westney \& Zaheer, 2001; Geppert, Matten \& Walgenbach, 2006). Thus, the interdisciplinary theory that explains business vis-àvis society should be developed through institutional theory in order to have it better understood. Institutional theory, however, attempts to clarify this phenomenon from a two-pronged approach, namely institutional dynamics and institutional diversity.

\section{Multinational Enterprises}

Transnational or MNEs are becoming influential in international manufacturing due to the increased availability of finance movement. International business development and operations have, therefore, altered corporate operating environments by introducing serious ecological ramifications.

Transnational conglomerates are, therefore, firms which manufacture global merchandises, looking for an inexpensive location to increase their profits, and unceasingly revolutionizing through a search for strategic ideas, including technology, product innovation, and novel corporate approaches. Similarly, the ownership, management, the strategy, and the structure are MNEs' key features (Root, 1994) emphasizing the originalities of ownership and transnational enterprises, as in the Unilever and Shell conglomerates owned by the British and the Dutch, respectively. Furthermore, MNEs are to be managed by administrators and CEOs, who are the citizens of the enterprise's country of origin, which is a mandatory requirement.

Typically, the headquarters are staffed with the management who understand the enterprise's country's priorities and the business strategy to be adopted, which includes global profit maximization, plus strategies characteristic of affiliate countries. Most often, promising multinational enterprises utilize a mixed world-oriented strategy which on its part is adaptable to the conditions of the local market.

F. R. Root (1994), therefore, describes an MNE as the mother company of global dimensions, which 
produces from different countries via its several divisions upon direct decisions made by its affiliate firms, implements international business strategies, marketing, provides finance and staffing. Moreover, most multinationals owe few obligations to the countries they are amalgamated with.

\section{Business Innovation}

Innovation is the knowledge of how to create value, involving the development and execution of new ideas so as to produce an entirely sophisticated, novel and improved products, processes and services (Hon, Bloom \& Crant, 2014). Deductively, innovation involves comprehensive and general management programs, including new practices and responsibilities through a revolutionized change of mindsets and values contingent upon necessities for a broad, continuous and systematic transformation.

Developments in technology, coupled with the changing dynamics of know-hows, can springboard innovation and strategic business transformation to the levels that, therefore, might encourage huge profits. However, business willingness to deploy obsolete technologies, which are cheaper and increase profits, although at a huge cost to corporate operating environments and countries, where environmental standards are weak and, most frequently, nonexistent, can increase government surveillance in that transnational conglomerates are forced to declare essential details, including site plans and ramifications for operating environments.

Meanwhile, technology is presumed to transform and facilitate business operations, increase profits and reduce production cost; yet, obsolete technologies are still being deployed in countries. While incessant environmental catastrophes necessitate know-hows for the environmentally sound and friendly methods of production, old technologies continue to be used, partly due to the sheer ignorance of the consequences for the business itself and the very operating environments.

Notwithstanding the foregoing, multinational enterprises are required to be socially acceptable in order for them to undertake legitimate operations and, therefore, they must embrace such practices and methods that encourage an efficient and effective technology use in order to ensure high returns on production factors and maintain the sustainability of their host environments. Thus, the business innovation recognized in technology must ensure a good and sound energy use for the purpose of achieving environmental safety and the sustainability of business operating environments. Typically, measures must include the introduction of the technologies that ensure cleaner and safer energy utilization. Intuitively, the enterprises that use the landmass involving clearing woodlots and forests are to be supportive of regenerative measures and contribute to providing the support initiatives that are environmentally friendly. Moreover, corporate managements are increasingly encouraged to instill environmentally responsible behavior in their workplaces, making the business innovation agenda meaningful to communities since innovation only transcends technology.

Proper environmental disclosures by and a proper reporting system of an MNE must reflect conditions and practices on the ground while exhibiting high value and responsibility obligations. They must also appropriately implement these values through the communication system in order to allow business human capital to be abreast of compliant injunctions. Audit disclosures, be they good or bad, are key to the continuous innovative practices of a business intended to influence the community understanding, acceptance and legitimacy.

Meanwhile, the international guidelines set forth are unheeded to since corporate ethics are nothing but what business perceives as its responsibility and, very often, depend on moral convictions. Perhaps the most tragic environmental disaster was the Union Carbide's accident in India in 1984, which caused more than 2,500 deaths and impairment to people (Zagury, Bernard, Leonard, Cheynier, Feldman, Sarin \& Gallo, 1986). While water pollution occurs primarily due to the discharge of industrial hazardous wastes into local water bodies, thus rendering local rivers unusable, a reduction in the quality of the air due to 
contamination in industrial centers, which leads to increased respiratory and other diseases.

The foregoing accounts clearly demonstrate a lack of the management's understanding of business externalities since the deployment of old technologies increases the problems of security, safety, and the quality of life, which in turn negatively affects a business and its operating environments.

\section{Corporate Responsibility Construct}

Corporate citizenship is an evolving concept defying definitional theories. A body of studies indicate many definitions, without those emerging in methodological identification problems. However, Bowen's definition (1953), which emphasizes the effects of corporate operations on society and communities, for which plans should be afoot in order to remedy them, is important. This definition unquestionably provides us with the leads for the current definitions and establishes a harmony between corporate authority and business responsibility.

While conceptualizing that a company is formed just to amass wealth is one reason, and just as deep thinking reveals other obligations that must be fulfilled, communities in which business activities take place should benefit from the wealth created, the social obligations of the business, according to A. B. Carroll (1999), covers the socio-economic, legalethical plus discretionary motivations. Undoubtedly, this definition is widely cited in modern corporate responsibility discussions.

The view that the prosperity of a business hinges high on environmental sustainability is supportive of the argument that a business must embrace the corporate responsibility agenda in order to compensate stakeholder communities. Thus, the social responsibilities agenda recognizes the fact that a business classifies its participants and integrates their values, necessities and ambitions in the policies, strategies and everyday activities of the organization.

To delineate the boundaries of corporate citizenship, A. B. Carroll (1999) establishes a four-pronged CSR principle, which includes economic, legal, ethical and philanthropic obligations. Economic responsibilities relate to the productive capacity of a business with respect to the creation of opportunities and ensuring optimal wages. To achieve these value creation objectives, other resources, including technology, are deployed. As the beneficiary of production proceeds, the business must fulfill its tax obligations for the purpose of developing the infrastructure of the country of its incorporation. Therefore, the economic responsibility of the business relates to delivering products and being profitable. Indeed, seven economic activities are delineated, which include satisfying customers by providing them with real-value commodities; earning profits for investors; creating new wealth; promoting social values (as their wages rise) through new jobs; defeating envy, treating people equitably and improving lives; promoting innovation; and avoiding the exploitation of the poor and underprivileged majority (Novak, 1996).

It is necessary that laws should be passed in order to regulate business behavior because corporations cannot be trusted for acting lawfully; hence the basis for legal responsibility. However, laws have a limited scope and only cover what is known and what is about to happen, since human actions determine the present circumstances of the law, and mere provision of a legal minimum for business conduct (which is reactive, instructing doing things) is inadequate.

Again, ethical responsibilities are people's moral rights exercised (Smith \& Quelch, 1993) and inclusive of social norms, institutions, and decisions, either expected (positive) or prohibited (negative), in society, although not written laws (Carroll \& Shabana, 2010). These injunctions, therefore, constitute business ethical obligations in stakeholder communities. Nowadays, society disregards productivity as moral justification for a business's generation of wealth, but as non-economic effects on society, which includes the employee and customer welfare system, stakeholders and business operating environments.

Discretionary obligations are the voluntary services that compensate people and societies because 
corporations operate in communities and their activities impact social values. Businesses are considered to be good citizens not by their economic performances, but rather by their social contributions that lift the poor from poverty and squalor. The contract of engagement is changing, and a business must serve wide-ranging social needs (Chewning, Eby \& Roels, 1990).

That corporate decision-making negatively affects communities and lives support an implied corporate/ social contract - a position strongly conceived by theorists, which spells out the social expectations of a business and business decision-makers' specific responsibilities (Beuachamp \& Bowie, 1983) because it has links with people's welfare and better living standards.

It further posits that social progress should weigh equal in balance with an enterprise's economic progress, and as social institutions, corporations must join hands and build structures amongst which the family and the educational system to improve living conditions (Chewning et al, 1990) are. The modern corporate world is characterized by professional managers, whose decisions impact communities (Miller, 1993), while exploiting societal resources so as to enrich corporate industrial objectives.

A growing consensus, therefore, suggests that a business must assist in solving corporate externalities since an enterprise's taxes alone are insufficient (Jamal \& Bowie, 1995) to ameliorate appalling environmental pollution. Indeed, a business possesses massive economic resources, including know-how and financial power (Lippke, 1996), to develop host communities if it so wishes.

\section{Sustainability}

Sustainability is variously defined by emphasizing preservation, thus entailing the satisfaction of the present needs of today's generation without compromising those of future generations (Visser, 2007) and long-term operation and envisioning a "more measured view" of resource consumption, simultaneously promoting growth (Hawkins, 2006).
This implies a generation's capability to sustain and keep the balance between the present and future needs (Blowfield \& Murray, 2008). Economist Robert Repetto's "Natural Capitalism" observes that when nation states deplete their mineral wealth, extinct the existing tree population, fishes, and wildlife, and cause the erosion of the soil and pollute springs and wells for mankind's immediate gains, a business should endeavor to adopt the production methods that encourage the stability of its operating environments (Abuyuan, Hawken, Newkirk \& Williams, 1999).

\section{METHODS}

The methodology is so designed to place the study in the scientific supposals and approaches reflecting the imperatives of research traditions. The field information and the secondary data obtained from the global online information system generated the overall dataset for the analysis. Indeed, the established (secondary) data provide the baseline for empirical data gathering, without which, however, empirical data collation is impossible.

Interviews were conducted with the representatives of the four mining transnational conglomerates (namely, Goldfields Ghana, Asanko Gold Ghana, Golden Star Resources, and African Mining Services) selected from the study's population. The interviewees include the corporate heads and their deputies, together with a host of the management officers manning the Security, Environment and Human Resource, and other portfolios. However, the investigation goes an extra mile to gather individual-level data from the community opinion leaders, the representatives of the institutions, as well as the non-governmental actors in mining exploration and development aimed at authenticating and cross-referencing the obtained company-level data.

The focused/semi-structured interview technique is deployed so as to gather field data for a thorough scrutiny, which encourages the investigation of interview details and processes. The onsite interviews also make the investigation investigate the studied 
objects. Macro-level information is obtained from the 30 management staffers of the mining transnational enterprises. Information on the impacts of mining on the communities is vigorously elicited, pursued and recorded. This information aims to discover the enterprises' management's understanding of the prospecting ramifications for social life and the environment, the safeguards and/or strategies adopted to curb these challenges, and how innovative technologies (whether old or new) alter business operating environments and natural ecological biodiversity. Information on the communitysupport and future considerations are also pursued. The investigation used the prepared questions subsequently altered for the purpose of dynamism of and adequate responses by the respondents.

In order to validate and cross-examine the companylevel data, the key fifty (50) participants were interviewed in the investigation. Although the individual-level information is merely aimed at crossreferencing the corporate data, it legitimizes the data collation process and empowers the investigation to identify misleading responses for the reconciliation purpose.

The research employs regression analysis in deriving the predictors and the unknown variables for the predictions of the study. The deployment of this technique, as an SPSS statistical package, stems from its measure for the cause and the effect within and among the variables. Meanwhile, as a statistical prediction tool used for the prediction of variables, given another when those variables are interrelated, it shows the mathematical average measurement of the relationships between the variables, and as such includes the measure which is the unknown variable predicted from the known. It reveals the estimates of the dependent variable from the independent ones, and also indicates the error involved in such approximations.

Moreover, regression identifies the correlation and the actual relationship that enables the estimation of the value which it is valid for. The dependent variable is chosen at random, whereas those fixed are the independent variables. In the regression calculation, one dependent measure is selected, but many independent variables are subjected to consideration. The research study indicates that the regression analysis only provides the confidence levels to the investigation that the predictions are all right and correct, instead of proving the claim.

In the main, the information collected and obtained from the interviews and the survey data are triangulated in the data analysis for obtaining the results. The triangulation methodology is justified and credited for integrating methods (Denzin, 1970; Denzin, 1992). Indeed, this method becomes an excellent starting point for an empirical research study and receives a much authorial acknowledgement (Sayer, 2000; Danermark, Ekström, Jakobsen \& Karlsson, 2002), hence its deployment for this study to incentivize the investigation into wide-ranging techniques and dissimilar phenomena.

\section{EMPIRICAL RESULTS}

The statistical experimental outcomes are intended to highlight the instruments and measures that are necessary for the authentication of the study's overarching of the aims and objectives, together with the assumptions in the other, for the purpose of synergizing the measurement findings. Indeed, the "Model Summary", which shows associations between the predictor and the outcome, indicates statistical significance, whereas the "Analysis of Variance" reports the regression equation and the variable inconsistency demonstrating the significance of the model significance and the predictive capability of the outcome variables. Supporting the aforementioned credibility, the p-values in the regression coefficients are statistically significant and, therefore, strengthen the predictors' predictive ability for unknown outcomes.

The $\mathrm{R}$ column (Table 1) represents the variable, where $\mathrm{r}=0.977^{\mathrm{a}}$, demonstrating the strong relationships between the variables (the predictor and the outcome). In a similar fashion, the $\mathrm{R}^{2}(0.955)$, which is statistically significant, determines the variance 
proportion of the outcome. It, therefore, means that the model predictor has the capability of predicting the outcomes. The overall standard error (0.30060) shows an insignificant value, and makes the variables closer to the regression limit.

Table 1 Model Summary

\begin{tabular}{c|cccc}
\hline Mode & $R$ & R Square & $\begin{array}{c}\text { Adjusted } \\
\text { R Square }\end{array}$ & $\begin{array}{c}\text { Std. Error of the } \\
\text { Estimate }\end{array}$ \\
\hline 1 & $.977 a$ & .955 & .952 & .30060 \\
\hline
\end{tabular}

Predictors: (Constant), The board's diversity ensures an effective CG for the CSR, Decoupling the CSR from the Corporate Affairs Department attracts a better response from the management, A disregard for the CG rules negatively affects the CSR.

Source: Author

The analysis of variance (Table 2), also called ANOVA, describes the regression equation and the variability (inconsistency). The Source column includes regression, both residual and total, where the corresponding values (69.722 and 3.253) denote the variability of the response variance. Thus, ANOVA determines the model significance and the predictive capability of the outcome variables. The $p<.001$ is statistically significant and, therefore, makes the model outcome predictor a suitable measure, where $\mathrm{F}$ $(3,36)=257.20, \mathrm{p}<.001$.
The $\mathrm{R}$ (Table 4) shows an association between the variables, where $r=0.886^{a}$, and signifies the predictor, and the reaction variables are comparable. Additionally, $\mathrm{R}^{2}(0.785)$ is the determinant of the variability of the variance, which is also statistically significant, meaning that the model can predict the research outcomes. Likewise, the entire standard error (0.21822) shows an insignificant value, which means the measures are nearer the regression domain.

Table 5 describes the computed equation and the variable inconsistency. The matrix consists of the Regression, Residual and Total, where the corresponding values (6.261 and 1.714) denote the unevenness of the response measure. Thus, ANOVA determines the model significance and the predictive capability of the outcome variables. The $p<.001$ indicates statistical significance and, therefore, makes the regression model a valid predictor of the outcome, where $F(3,36)=43.83, p<.001$.

\section{DISCUSSION}

This study examines the innovation of a business and its ramification with respect to its social accountability and environmental responsibility. It further discusses whether the innovation in and technological improvements of a business in the domain of the production practices and other

Table 2 ANOVA $^{a}$ (Analysis of Variance)

\begin{tabular}{cl|ccccc}
\hline \multicolumn{1}{c|}{ Model } & Sum of Squares & df & Mean Square & F & Sig. \\
\hline \multirow{3}{*}{1} & Regression & 69.722 & 3 & 23.241 & 257.203 & $.000^{\mathrm{b}}$ \\
& Residual & 3.253 & 36 & .090 & & \\
& Total & 72.975 & 39 & & & \\
\hline
\end{tabular}

a. Dependent Variable: The management have the insufficient knowledge of the business externalities and the impacts on the communities.

b. Predictors: (Constant), The board's diversity ensures an effective CG for the CSR, Decoupling the CSR from the Corporate Affairs Department attracts a better response from the management, A disregard for the CG rules negatively affects the CSR.

Source: Author 
management procedures lead to natural environment sustainability and stakeholder constituents. Evidence shows that corporate innovation is internalized for the benefits of a business, not the external stakeholder constituencies, deflating and negating the paper's overarching objective that business innovation facilitates environmental sustainability and/or responsibility, and social accountability.

Contrary to the general perception that, through research and development (R\&D), the know-how and innovation of a business advances the host communities' interest in involving itself in ecologically sound practices, an enterprise's innovation, alas, is found to be purposefully designed to seek the expansion, growth, and capital accumulation of such a business. The ensuing deliberations validate the suppositions alleged in the study.
Table 3 contains the p-value of each term and the statistical tests for the constructs and the coefficients. The p-value (.001, .001 and .002) of each term is statistically significant, showing the predictor is prominent to be interpreted because the variations in the predictor are related to the changes in the response variables. That the selected variables are statistically significant, whereas the abundant evidence that the constructs are monotonically correlated and, therefore, validate the extrapolations of the research means that the results are assumptions-supportive. Additionally, the t-values (-22.756, 24.515, -3.368) indicate the variations of little significance relative to the constructs and are comparable and suitable for making predictions. Likewise, the standard errors $(.135, .107$ and .098$)$ show the insignificant values that are indicative of the fact that the measures are closer to the regression limit, thereby supporting the research expectations.

Table 3 Regression Coefficients ${ }^{\mathrm{a}}$

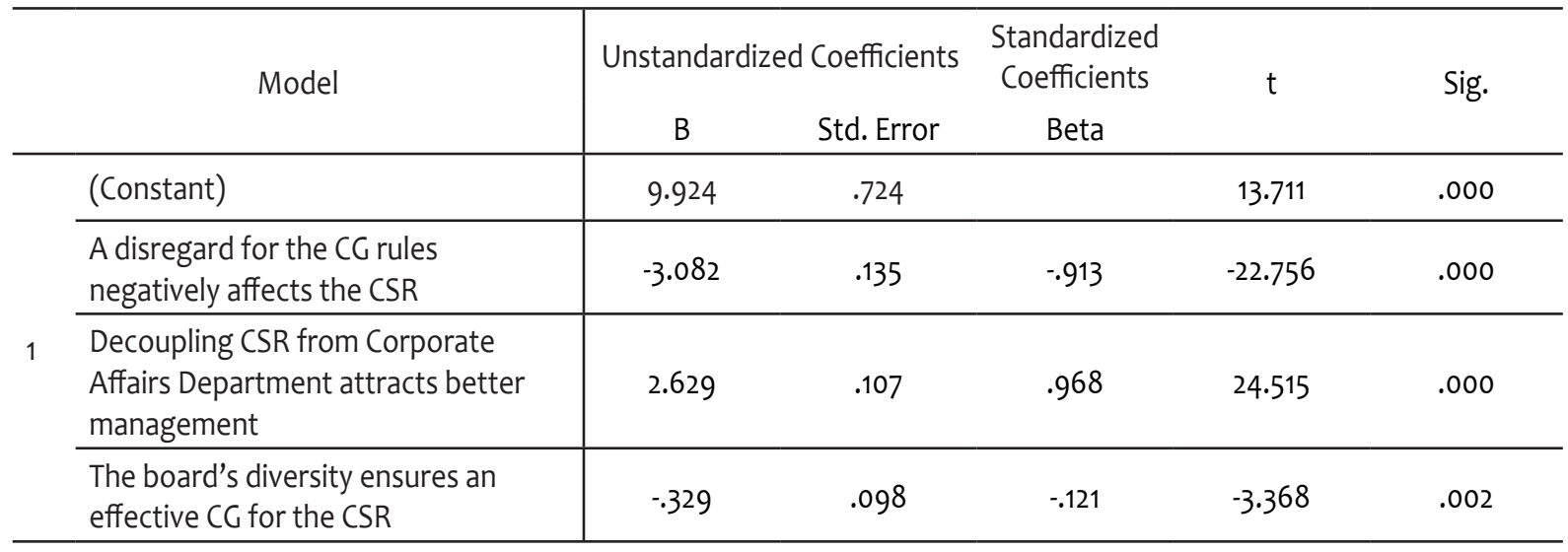

Dependent Variable: The management have the insufficient knowledge of the business externalities and the impacts on the communities.

Source: Author

Table 4 Model Summary

\begin{tabular}{c|cccc}
\hline Model & R & R Square & Adjusted R Square & Std. Error of the Estimate \\
\hline 1 & $.886 a$ & .785 & .767 & .21822 \\
\hline
\end{tabular}

Predictors: (Constant), A disregard for the CG rules negatively affects the CSR, A weak corporate board disincentivizes the CSR, Decoupling CSR from the Corporate Affairs Department attracts better management. 
Table 5 ANOVA $^{a}$ (Analysis of Variance)

\begin{tabular}{|c|c|c|c|c|c|c|}
\hline & Model & Sum of Squares & df & Mean Square & $\mathrm{F}$ & Sig. \\
\hline \multirow{3}{*}{1} & Regression & 6.261 & 3 & 2.087 & 43.825 & $.000^{\mathrm{b}}$ \\
\hline & Residual & 1.714 & 36 & .048 & & \\
\hline & Total & 7.975 & 39 & & & \\
\hline
\end{tabular}

Dependent Variable: The CSR is an inadequate compensation for corporate profiting and rent-seeking.

Predictors: (Constant), A disregard for the CG rules negatively affects the CSR, A weak corporate board disincentivizes the CSR, Decoupling the CSR from the Corporate Affairs Department attracts better management.

Source: Author

Meanwhile, the constant of the unit change of the model (9.924) results in this measure (-3.082) of change in "A disregard for the CG rules negatively affects the CSR". Likewise, the constant of a single-unit change of the model (9.924) leads to a change in the measures (2.629 and -.329) and confirms the "Decoupling the CSR from the Corporate Affairs Department attracts better management" and 'The board's diversity ensures an effective CG for the CSR", respectively.

The ordinary interpretation of the statistical results shows that little is done about the externalities of the business and their ramifications for the stakeholder communities and the environment because the management possess the knowledge and understanding that are scanty, which corroborates the proof that the self-regulation of corporate commitments is an inadequate strategy for the implementation of the stakeholder initiative and, therefore, should be formalized.

A conclusion is, therefore, drawn that the leadership of the management of a business, including transnational ones, hardly understand the practical implications of corporate activities for sustainability. Intuitively, pollution is an after-effect observable in the illness of humans, a loss of the fauna and flora, and a reduction in the quality of the aquatic resource, which regrettably are noticeable only to the human eye. Thus, with an adequate knowledge and understanding, concrete steps will be taken in order to reduce the causative factors and also lessen the impacts. No doubt, transnational enterprises externalize the production cost, resulting in horrific and catastrophic environmental ramifications, poverty, and health problems (Aid, 2004b; Armstrong, 2005; Visser, 2010).

Again, the result also demonstrates a huge piece of evidence showing that the current self-regulation of corporate commitments and undertakings is informal, ad hoc, and unsystematic, and that it delivers scanty outcomes, validating the proposition for formalizing the strategy to incentivize appropriate and compensatory outcomes.

In a nutshell, the paper demonstrates that the corporate management has the insufficient knowledge of the deleterious activities of the business and their impacts on the sustainability of the communities, as a disservice to corporations, themselves, and the stakeholder communities, since the cost of externalities affects both the business and its operating environments alike.

Similarly to Table 5, Table 6 shows the regression results including the p-values and the coefficients. The statistically significant p-value $(<0.05)$ demonstrates that the predictor has to be taken into consideration and reported since changes in the predictors' variables affect the response variables.

Therefore, the three coefficients (.429, .429 and .571) indicate statistical significance (.001 x 3), meaning the constructs are monotonically related. Moreover, the t-values $(3.674,4.409,5.060)$ indicate the difference of small significance in the variables of the model, suggesting that the constructs share a high degree of association. Furthermore, the standard errors (.117, 
Table 6 Regression Coefficients ${ }^{\mathrm{a}}$

\begin{tabular}{|c|c|c|c|c|c|c|}
\hline & \multirow[t]{2}{*}{ Model } & \multicolumn{2}{|c|}{ Unstandardized Coefficients } & \multirow{2}{*}{$\begin{array}{c}\text { Standardized } \\
\text { Coefficients } \\
\text { Beta } \\
\end{array}$} & \multirow[t]{2}{*}{$\mathrm{t}$} & \multirow[t]{2}{*}{ Sig. } \\
\hline & & B & Std. Error & & & \\
\hline \multirow{4}{*}{1} & (Constant) & -.857 & .505 & & -1.697 & .098 \\
\hline & $\begin{array}{l}\text { A weak corporate board } \\
\text { disincentivizes the CSR }\end{array}$ & .429 & .117 & .365 & 3.674 & .001 \\
\hline & $\begin{array}{l}\text { Decoupling the CSR from the } \\
\text { Corporate Affairs Department } \\
\text { attracts better management }\end{array}$ & .429 & .097 & .478 & 4.409 & .000 \\
\hline & $\begin{array}{l}\text { Disregard for CG rules negatively } \\
\text { affects CSR }\end{array}$ & .571 & .113 & .512 & 5.060 & .000 \\
\hline
\end{tabular}

Dependent Variable: The CSR is an inadequate compensation for corporate profiting and rent-seeking.

Source: Author

.097 and .113), which are the average distance from the regression line, show insignificant measures, indicating the measures are closely related.

More importantly, the value of the constant (-.857) implies that the model takes the mathematical value of -0.857 given to the independent predators. Therefore, the unit change in the constant (-.857) results in this measure (.429) of change in "A weak corporate board disincentivizes the CSR". Furthermore, the variation of the model's constant unit (-.857) changes the measures (.429 and .571) and confirms the validity of the "Decoupling the CSR from the Corporate Affairs Department attracts better management" and "The board's diversity ensures an effective CG for the CSR", respectively.

The foregoing means that, on the pretext of corporate commitments, which are woefully scanty (Frynas, 2005) owing to the absence of the policy on the regulation and implementation of initiatives, corporate taxes and royalties are insignificantly negligible for any development of the infrastructure that make the communities in which a business operates worse off. Additionally, certain transnational conglomerates do not even pay taxes at all (Akabzaa, 2009), either due to weak or due to non-existent policies and regulations (Auty, 1998). This, therefore, supports the consensus that the discussion on the management of the resource wealth has shifted from te needed, careful and measured industrial policy to the propositions for independent institutions and investment funds (Harberger, 1994; McMahon, 1997; Auty \& Gelb, 2001; Frezzolini, Teofoli, Cianchini, Barduagni, Ruffelli, Ferranti, Puddu \& De Pita, 2002).

The above confirms the fact that the business does little to ensure its social accountability and environmental responsibility, though corporate profits continue to grow. The exploitation of the stakeholder resources for the purpose of making profits hardly serves the interest of the business since the increased financial performance might be perceived as less socially good, resulting in rising income in favor of the investor and the upper management (Barnett, 2007), and may motivate cynicism and violence from the local population.

The call for the formalization of self-regulation is for the purpose of ensuring the sincerity of the business, which otherwise will sanction the stereotypes for increased profits and business externalities. No wonder T. M. Devinney (2009) argues that environmental sustainability and corporate accountability to its stakeholder constituencies have been carelessly managed. 


\section{CONCLUSION}

Business innovation and its effects on environmental sustainability and social accountability were examined. We were determined to discover whether managers understand business negative implications for stakeholder communities and the environment or not, and whether the self-regulation of corporate commitments is a poor strategy for the execution of the stakeholder's initiative. Statistical evidence proves that, contrary to the generally held opinion, corporate innovation seeks to benefit the environments in which a business operates and support environmental accountability, and the gains are rather internalized so as to promote the expansion, growth, and profitability of an enterprise.

Since innovation, which provides new knowledge and thinking, is skewed towards the success of a business, there is little room for managers to be motivated for pursuing environmental sustainability and social accountability concerns because corporate learning is becoming innovation for the success of a business. In this view, the assumption that "The management's insufficient and poor knowledge of business externalities and insufficient understanding lead to environmentally unfriendly production practices" is validated, and the reason why social development, sustainability, and business ethics have remained peripheral, and why the standards having been adopted by the majority of companies, including the internationally recommended regimes and sets of initiatives and guidelines, have all failed to halt the destruction of the natural environment and host communities (Visser, 2010).

In another development, the unification of social responsibility and environmental accountability has received some modest treatment in the literature with a rather casual alignment. This is for the reason of the fact that corporations desire to adopt guidelines, ethics and standards, and also adhere to the aspirations of external stakeholder constituencies while transiting to the existing economic and political scene and practically accommodating and internalizing environmental externalities (Hertel, 2009) so as to increase the commitments of a business towards a conducive working atmosphere and the preservation of ecology via the acquisition of wealth (Mandelbaum, 2007), thereby rendering the considerations of social and environmental sustainability mutually exclusive. The result establishes the fact that CSR initiatives have been scanty and disproportionately minor in comparison with corporate profits, thus confirming the assumptions.

The continuous viability of a business, including multinational enterprises on the global market, is reliant on innovation for the development of processes and methods, and the reformulation of the development of the product. Given that a business always does the right thing, the growing voice to maintain its operating communities and be environmentally accountable is needless and timewasting. For instance, environmental degradation and/or the complicated market-inadequate measurements for corporate externalities continue to diminish social-ecological resources. However, the analysis reveals that business managers hardly understand corporate externalities and, therefore, do not plan their reduction. This means that business innovation in production processes, methods, and research and development is, at best, internalized for increased profits against environmental sustainability. Astonishingly, corporate innovation correlates with the social accountability and environmental sustainability agenda; yet, managers have an insufficient knowledge of and understanding for business externalities, for which reason the prospects of innovation have no relevance for host communities and the environment.

Indeed, deploying knowledge for the purpose of creating value for entirely sophisticated novel and improved products, processes and services also means that such undertakings should be socially and environmentally sustainable. The paper, unfortunately, wonders whether business innovation is an inversion of environmental pollution and degradation.

Again, the results encapsulating corporate responsibility cannot compensate for the wealth generated from stakeholder communities because 
social responsibility initiatives are poorly funded and implemented. In this regard, environmental responsibility suffers as commitments are scanty and underfunded, affecting environmental initiatives and CSR interventions. In order to make the CSR compensate for business profits and rent-seeking, the ineffectual self-regulation strategy for social accountability and environmental responsibility should be supported through the stakeholder governance model for results.

Empirical data collation is expensive, especially when involving onsite interviews that require inexhaustible funds to conduct. Thus, the funds inadequacy together with human capital restricts and constrains large data for analysis. Managers' insufficient knowledge of and understanding for externalities leads to poor corporate commitments and poor environmental accountability and/or sustainability, which is novel in contemporary research and we hope it will be the focus of further academic scrutiny.

To conclude, we regret the comment made by a powerful individual on Earth that "environmental pollution and degradation are a hoax", which reflects a bigger picture of ignorance amongst the majority of the world's nearly 7 billion population; that is a reason why it is increasingly difficult to cure environmental malice and ensure the stability and ecological sustainability of stakeholder communities.

\section{REFERENCES}

Abuyuan, A., Hawken, I., Newkirk, M., \& Williams, R. (1999). Waste Equals Food: Developing a Sustainable Agriculture Support Cluster for a Proposed Resource Recovery Park in Puerto Rico 1999. CiteSeer ${ }^{x}$.

Aguilera, R. V., Williams, C. A., Conley, J. M., \& Rupp, D. E. (2006). Corporate governance and social responsibility: A comparative analysis of the UK and the US. Corporate Governance: An International Review, 14(3), 147-158. doi. org/10.1111/j.1467-8683.2006.00495.x

Aid, C. (2004a). Behind the mask: The real face of corporate social responsibility. London, UK: Christian Aid
Aid, C. (2004b). Behind the mask: The real face of CSR. London, UK: Christian Aid.

Akabzaa, T. (2009). Mining in Ghana: Implications for national economic development and poverty reduction. In B. Campbell (Ed.). Mining in Africa: Regulation and development (pp. 25-65). Pluto Press, IDRC.

Armstrong, E. (2005). Integrity, transparency, and accountability in public administration: Recent trends, regional and international developments, and emerging issues. United Nations, Department of Economic and Social Affairs, 1-10.

Auty, R. M. (1998). Social sustainability in mineral-driven development. Journal of International Development, 10(4), 487500 .

Auty, R. M., \& Gelb, A. H. (2001). The political economy of resource abundant states. Resource abundance and economic development, 126-144, Working Paper, Washington, DC: World Bank.

Banerjee, S. B. (2000). Whose land is it anyway? National interest, indigenous stakeholders, and colonial discourses: The case of the Jabiluka uranium mine. Organization $\mathcal{E}$ Environment, 13(1), 3-38. doi.org/10.1177/1086026600131001

Barnett, M. L. (2007). Stakeholder influence capacity and the variability of financial returns to corporate social responsibility. Academy of management review, 32(3), 794-816. doi.org/10.5465/amr.2007.25275520

Bessant, J., \& Tidd, J. (2007). Innovation and entrepreneurship. Leicester, UK: Wiley, John \& Sons.

Beuachamp, T., \& Bowie, N. E. (1983). Ethical theory and business. Englewood Cliffs: NJ: Prentice-Hall.

Blowfield, M., \& Murray, A. (2008). Corporate responsibility: A critical overview. Oxford, Oxford University Press.

Bowen, H. R. (1953). Social Responsibilities of the Businessman. NewYork, NY: Harper\&Row.

Bryman, A. (1999). The Disneyization of society. The Sociological Review, 47(1), 25-47. doi.org/10.1111/1467-954X.00161

Carroll, A. B. (1999). Corporate social responsibility: Evolution of a definitional construct. Business \& society, 38(3), 268-295. doi.org/10.1177/000765039903800303 
Carroll, A. B., \& Shabana, K. M. (2010). The business case for corporate social responsibility: A review of concepts, research, and practice. International journal of management reviews, 12(1), 85-105. doi.org/10.1111/j.1468-2370.2009.00275.x

Chewning, R. C., Eby, J. W., \& Roels, S. J. (1990). Business through the eyes of faith. HarperOne.

Crouch, C. (2004). Post-democracy. Polity Cambridge.

Danermark, B., Ekström, M., Jakobsen, L., \& Karlsson, J. C. (2002). Explaining society. Critical realism in the social sciences. London, UK: Routledge, Taylor \& Francis Group.

Denzin, N. (1970). Strategies of multiple triangulation. In N. Denzin (Ed.). The research act in sociology: A theoretical introduction to the sociological method, (pp. 297-313). New York, NY: McGraw-Hill

Denzin, N. (1992). The many faces of emotionality: Reading persona. Investigating subjectivity: Research on lived experience, $17-30$.

Devinney, T. M. (2009). Is the socially responsible corporation a myth? The good, the bad, and the ugly of corporate social responsibility. The Academy of Management Perspectives, 23(2), 44-56. doi.org/10.5465/amp.2009.39985540

Elkington, J. (1997). Cannibals with forks: The triple bottom line of twentieth-century business. Oxford, US: John Wiley \& Son Ltd

Employment Green Paper. (2001). Promoting a European Framework for Corporate Social Responsibility: Green Paper. Office for Official Publications of the European Commission.

Frezzolini, A., Teofoli, P., Cianchini, G., Barduagni, S., Ruffelli, M., Ferranti, G., Puddu, P., \& De Pita, O. (2002). Increased expression of eotaxin and its specific receptor CCR3 in bullous pemphigoid. European journal of dermatology: EJD, 12(1), 27-31.

Frynas, J. G. (2005). The false developmental promise of corporate social responsibility: Evidence from multinational oil companies. International affairs, 81(3), 581-598.

Garriga, E., \& Melé, D. (2004). Corporate social responsibility theories: Mapping the territory. Journal of Business Ethics, 53(1-2), 51-71. doi:10.1023/B:BUSI.0000039399.90587.34

Geppert, M., Matten, D., \& Walgenbach, P. (2006). Transnational institution building and the multinational corporation: An emerging field of research. Human Relations, 59(11), 14511465. doi.org/10.1177/0018726706072888
Graedel, T., Allenby, B., \& Linhart, P. (1993). Implementing industrial ecology. IEEE Technology and Society Magazine, 12(1), 18-26. doi:10.1109/44.192717

Harberger, A. C. (1994). New insights into the growth process: Indian Council for Research on International Economic Relations.

Hawkins, D. (2006). Corporate social responsibility: Balancing tomorrow's sustainability and today's profitability. London, UK: Palgrave Macmillan

Hertel, S. (2009). Human rights and the global economy: Bringing labor rights back in. Md. J. Int'l L. 24(1), 257-269.

Hon, A. H., Bloom, M., \& Crant, J. M. (2014). Overcoming resistance to change and enhancing creative performance. Journal of management, 40(3), 919-941. doi. org/10.1177/0149206311415418

Jamal, K., \& Bowie, N. E. (1995). Theoretical considerations for a meaningful code of professional ethics. Journal of Business Ethics, 14(9), 703-714.

Jermier, J., Forbes, L., Benn, S., \& Orsato, R. J. (2006). The new corporate environmentalism \& green politics. In S. R. Clegg, C. Hardy, T. B. Lawrence, \& W. R. Nord (Eds). The Sage handbook of organization studies. doi:10.4135/9781848608030. n22

Kinderman, D. (2012). 'Free us up so we can be responsible!'The co-evolution of corporate social responsibility and neoliberalism in the UK, 1977-2010. Socio-Economic Review, 10(1), 29-57. doi:10.1093/ser/mwr028

Lippke, R. (1996). Setting the terms of the business responsibility debate," in Ethics in the Workplace: Selected Readings in Business Ethics. Larmer, RA (Ed), West Publishing Company, Minneapolis/St. Paul, MN. St. Paul, MN.

Mandelbaum, D. G. (2007). Corporate sustainability strategies. Temple Journal of Science Technology \& Environmetal Law, 26, $27-42$.

Matten, D., \& Moon, J. (2008). "Implicit" and "explicit" CSR: A conceptual framework for a comparative understanding of corporate social responsibility. Academy of management review, 33(2), 404-424. doi.org/10.5465/amr.2008.31193458

McMahon, G. (1997). The natural resource curse: Myth or reality? Economic Development Institute, Washington, DC: World Bank. 
Miller, T. (1993). The well-tempered self Citizenship, culture, and the postmodern subject. The Johns Hopkins University Press.

North, D. C. (1990). Institutions, Institutional Change and Economic Performance. Cambridge, US: Cambridge university press.

Novak, W. J. (1996). The People's Welfare: Law and Regulation in Nineteenth-century America. North Carolina, US: Univrsity of North Carolina Press.

Orenstein, P. (2011). Cinderella Ate my Daughter: New York, NY: HarperCollins.

Orlitzky, M., \& Swanson, D. (2008). Toward Integrative Corporate Citizenship: Research Advances in Corporate Social Performance. London, UK: Palgrave Macmillan UK.

Parkinson, J. (2003). Disclosure and corporate social and environmental performance: Sompetitiveness and enterprise in a broader social frame. Journal of Corporate Law Studies, 3(1), 3-39. doi.org/10.1080/14735970.2003.11419892

Ritzer, G., \& Jurgenson, N. (2010). Production, consumption, prosumption the nature of capitalism in the age of the digital 'prosumer'. Journal of consumer culture, 10(1), 13-36. doi.org/10.1177/1469540509354673

Root, F. R. (1994). Entry Strategy for International Markets. New York, NY: Lexington Books.

Roy, W. G. (1999). Socializing capital: The rise of the large industrial corporation in America. Princeton, US: Princeton University Press.
Sayer, A. (2000). Realism and Social Science. London, UK: SAGE Publications.

Smith, N. C., \& Quelch, J. A. (1993). Ethics in Marketing. JSTOR.

Spaargaren, G., \& Mol, A. P. (1992). Sociology, environment, and modernity: Ecological modernization as a theory of social change. Society \& natural resources, 5(4), 323-344. doi. org/10.1080/08941929209380797

Visser, W. (2007). Corporate sustainability and the individual. Cambridge Programme for Sustainability Leadership, Paper Series No 1.

Visser, W. (2010). The age of responsibility: CSR 2.0 and the new DNA of business. Journal of Business Systems, Governance and Ethics, 5(3), 7-22. doi:10.15209/jbsge.v5i3.185

Vogel, D. (2006). The Market for Virtue. Washington, US: Brookings Institute press.

Westney, D. E., \& Zaheer, S. (2001). The multinational enterprise as an organization. The Oxford handbook of international business, 1, 101-124. doi:10.1093/ oxfordhb/9780199234257.003.0013

Zagury, D., Bernard, J., Leonard, R., Cheynier, R., Feldman, M., Sarin, P., \& Gallo, R. C. (1986). Long-term cultures of HTLV-III-infected T cells: A model of cytopathology of T-cell depletion in AIDS. Science, 231, 850-854.

Received on $3^{\text {rd }}$ November 2018, after revision, accepted for publication on $12^{\text {th }}$ December 2018 Published online on $28^{\text {th }}$ December 2018

Alphonse Kumaza is a senior tourism officer at the Ministry of Tourism, Arts and Culture, Ghana, and works at the Research and Statistics Department. Since 2015, he has been awarded a scholarship for a Ph.D. degree in Business Administration, majoring in Enterprise Strategic Management and Managerial Economics at the School of Management, Huazhong University of Science \& Technology (HUST), Wuhan, China. His research interests are in Corporate Responsibility, Corporate Governance, and Policy. 


\title{
ISPITIVANJE POSLOVNIH INOVACIJA U KONTEKSTU DRUŠTVENE I EKOLOŠKE ODGOVORNOSTI: EMPIRIJSKE SINTEZE IZ GANE
}

\author{
Alphonse Kumaza \\ Huazhong University of Science \& Technology, School of Management, Hongshan District, \\ Wuhan City, Hubei Province, People's Republic of China
}

Korporativne inovacije i primena tehnologija za poboljšanje poslovnih dobiti predstavljaju trajni fokus kojem gravitira menadžment. U ovoj studiji se istražuju inovacije i njihova sposobnost da obezbede društvenu i ekološku odgovornost. Inovacije su neophodne za rast, održavanje udela na tržištu i neprekidno širenje i istraživanje poslovnih prilika, što ipak i dalje predstavlja poteškoću u obezbeđivanju održivih zajednica. Statistički rezultati sprovedene SPSS analize pokazuju da poslovno inovativne tehnologije i nove sposobnosti razmišljanja nisu zamišljene tako da se njima promovišu ekološka odgovornost i društveno blagostanje, već da se korporacijama obezbedi veći rast. Slabo razumevanje eksternalija preduzeća od strane menadžmenta privrednog društva doprinosi slabim ekološkim performansama istog. Ovaj doprinos, koji je istovremeno i predmet potencijalnih budućih istraživanja, otkriva i nesposobnost korporacija da promovišu održive zajednice interesnih grupa i ekološku odgovornost, što je u suprotnosti sa percepcijama po kojima poslovne inovacije rade u korist ekološke održivosti.

Ključne reči: održivost, korporativna odgovornost, inovacije, korporativno upravljanje, zagađenje, eksternalije, Gana

JEL Classification: M14, O31, Q56 